\title{
Determining Secondary School Students' Knowledge and Awareness about Antarctica
}

\author{
Nazihan Ursavaş ${ }^{1 *}$, Raif Kandemir² \\ ${ }^{1}$ Department of Mathematics and Science Education, Faculty of Education, Recep Tayyip Erdogan University, Rize, Turkey \\ ${ }^{2}$ Department of Geological Engineering, Faculty of Engineering, Recep Tayyip Erdogan University, Rize, Turkey \\ *Corresponding Author nazihan.ursavas@erdogan.edu.tr
}

\begin{abstract}
Antarctica has been an object of interest for a long. It is considered important to increase individuals awareness and knowledge about Antarctica. The accuracy of individuals' scientific knowledge plays an important role in creating the awareness. In this study, the 349 secondary school students' knowledge and awareness about Antarctica was determined quantitatively with a questionnaire. Nineteen questions, including current topics were prepared. that addressed from biological geographic and climatic perspectives. According to the findings, 40\% of the students thought Antarctica is in the North Pole, 42.6\% thought polar bears and penguins live together; $46.6 \%$ thought Antarctica is best visited during summer months, 70.5\% thought most glaciers are located in the northern hemisphere. Based on these findings, it can be said that students have inadequate and alternative conceptions about Antarctica. Studies can be conducted to determine how best to increase students' awareness.
\end{abstract}

Keywords Antarctica, Knowledge, Awareness, Secondary school students

\section{INTRODUCTION}

The Earth's polar regions where can provide an insight into fundamental Earth system processes are crucial for regulating the world climate (Ricci and Egerton, 2010). Besides, they are the primary resources of freshwater, which is the main source of life and the most critical molecule that distinguishes Earth from other planets. Still, Earth's water's origin is a mystery (Drake, 2015; ElkinsTanton, 2011; Genda, 2016; Marty \& Yokochi, 2006; Robert, 2001). A possible solution to this mystery plays a crucial role in reading the world's evolutionary history and modern structure, exploring water, and measuring its quantity on different planets today (Wu et al., 2018). In understanding the evolutionary history of the world, the information that water itself contains is also crucial. This critical information is hidden mostly in glaciers, namely the solid state of water since glaciers are rare sources that can hold information about climate changes dating back thousands of years in air bubbles trapped in them (Benn \& Evans, 2010; Dahl-Jensen, 2018). Thanks to such information obtained from the glaciers, the causes of the glacial ages' changes can be better highlighted. Future climatic changes can be predicted to take necessary precautions in advance (Azzolini, Campus \& Weber, 2012; Baydemir, 2019).

As it is known, the regions with intense glacial layers are located around the North and South Poles. Although glaciers constitute only approximately $2.1 \%$ of our planet's total water, they inhold an essential volume of usable water resources. $\quad 90 \%$ of these glaciers are located in Antarctica and 9\% in Greenland, the two poles of Earth (Lucchitta, \& Ferguson, 1986). However, the glaciers at each of the poles are unique on account of a significant difference. The glaciers in Greenland consist of sea glaciers that contain saltwater, whereas those in Antarctica are made up of freshwater. Although Antarctica's icy landscape looks distant, scientific research in this region can give insight into the changes that matter to the entire planet (The National Academy of Sciences, 2011). Today, a wide array of scientific studies are being conducted on Antarctica by many countries searching fossils, lake ecosystems, geological, rock layers and layering, how the earth surface processes, archaeological, the structure and properties of glacier ice, its formation and the interactions

Received: 23 August 2020

Revised: 21 November 2020

Published: 28 November 2020 
of ice accumulation with climate, meteorological and climatological aspects along with impact monitoring and anthropogenic activities on the continent (Benayas et al., 2013). Recently, Turkey has also contributed to such studies. Istanbul Technical University Polar Research Application and Research and Centre (PolReC) was established as the first Turkish organization specialized in the Polar Regions. With the coordination support of this center, the Turkish Antarctic Science Expedition I (TAEI) was held in 2017. It had its sequels as TAE-II and TAEIII in the years 2018 and 2019, respectively, within the "Turkish Antarctic Science Base Project" (in Karahalil, Özsoy, Oktar, Yirmibeşoğlu, \& Vural, 2018). Even another expedition to Antarctica was realized in 2020 (TAE-IV).

Antarctica has been an object of interest for a long. On top of everything, the existing descriptive scientific studies respecting Antarctica attract scientists' attention. Issues such as stratospheric ozone depletion and enhanced ultraviolet effects, environmental and climatic archive from ice cores, detection of anthropogenic pollution, the study of global climate change (such as the carbon cycle and sea level), and analysis of unique collections of meteorites have attracted and focused unprecedented international attention on Antarctica (Drewry, 2009). Besides, most of the clean water needed for the continuation of life is frozen in Antarctica. These waters are in danger due to environmental issues (Gröndahl, Sidenmark, \& Thomsen, 2009). It is thought that more information should be in hand about Antarctica, and awareness should be raised in individuals about this continent, which does not belong to any particular person or state. In addition to supporting Antarctica's expeditions, PolReC also carries out studies to raise awareness of individuals. These studies include sharing of the knowledge and experiences acquired by the scientists who visited the continent with students, various scientific club studies, interviews, seminars, or painting contests (Karahalil, Özsoy, Oktar, Yirmibeşoğlu, \& Vural, 2018; Vural, Yirmibeşoğlu, Oktar, \& Özsoy, 2018). Other countries are engaged in awareness-raising works about Antarctica. In particular, the Ministry of Education of New Zealand encourages studies in this area and integrates Antarctica content into its formal education curriculum (McFadyen, 2011). Australia is developing activity-based content for teachers to increase knowledge and awareness about Antarctica and is distributing the books compiled of such contents to all schools with the support of the Ministry of Education (Australian Science Teacher Association, 2007).

What is more, the American National Science Foundation (NSF) implemented a Project for the International Polar Year to increase societal awareness. They chose 27 students and teachers from secondary and tertiary educational institutions. The group was first trained accordingly, and then they toured Antarctica on a field trip (Garcia, Robertson, Lougheed, Tweedie, \& Velasco, 2013).
One influential factor for increasing the awareness of individuals about Antarctica is undoubtedly the storage of $69 \%$ of waters that can be used by living things on that continent (USGS, 2020). These glaciers will melt mainly due to climate change, and all that freshwater will be mixed with saltwater leading to the improbability of using such water or its contamination otherwise. This result in itself poses a significant threat to humanity about access to water. Besides, the melting of the glaciers on this continent may endanger life due to severe rises at sea level in the future (Benn, \& Evans, 2010). Today, water can be used and easily accessible, but it is at risk because of the misuse of water and wrong policies; this ultimately places more pressure on the glaciers, like the world's carboy (Bastmeijer, \& Roura, 2008). The accuracy of individuals' scientific knowledge plays an essential role in creating awareness (Salazar, 2012; Shabudin, Rahim \& Ng, 2016 ). However, individuals do not possess sufficient information about the environment (Özbebek-Tunç, Akdemir \& Düren, 2012), and it is stated that scientific information from the polar regions boosts people's knowledge of the environmental issues facing the world. Increasing the knowledge and awareness about the continent will both promote the continent and acknowledge its importance. Starting to raise awareness at an early age is useful for training conscious individuals (Ursavaş, \& Aytar, 2018). At the following stage, revealing the individuals' perceptions and levels of understanding of the subject can guide such works' context, manner, and direction (Karataş, Köse, \& Coștu, 2003). This particular study aimed to identify the knowledge and awareness of secondary school students about Antarctica, and answers were sought for the following research questions for this purpose. What knowledge do secondary school students have about various geographical issues related to Antarctica?. What knowledge do secondary school students have about various biological issues related to Antarctica?. What knowledge do secondary school students have about various climatic issues related to Antarctica?

\section{METHOD}

\subsection{Study Design and Participants}

This study was conducted as a descriptive survey research. There are several types of descriptive research. To reveal students' knowledge about Antarctica before the speech on Antarctica and due to produce a "snapshot", cross-sectional survey research was run for this study (Cohen, Manion, \& Morrison, 2007). The study's universe consists of secondary school students, and purposive sampling was used to choose the sample. It is purposive because students were chosen among from who attend the scientific speech. Students took part in the study 
Table 1 Questions and answers about the North Pole and the South Pole

\begin{tabular}{|c|c|c|c|c|c|}
\hline \multirow[b]{2}{*}{ Questionnaire Item } & \multicolumn{2}{|c|}{ North Pole } & \multicolumn{2}{|c|}{ South Pole } & \multirow[b]{2}{*}{ Total } \\
\hline & Female & Male & Female & Male & \\
\hline Q2- Which pole of the world harbors more glaciers? & 129(38.3) & $108(32.2)$ & $53(15.7)$ & $46(13.8)$ & 336 \\
\hline $\begin{array}{l}\text { S8- In which hemisphere of the world is Antarctica } \\
\text { located? }\end{array}$ & $79(23.2)$ & $57(16.8)$ & 104(30.6) & $100(29.4)$ & 340 \\
\hline
\end{tabular}

voluntarily. As a procedural requirement, necessary permissions were obtained from the Provincial Directorate of National Education. Once the implementation stage was launched, data were collected during the 2019-2020 academic year, fall semester, outside the classroom hours, and without interrupting regular educational and instructional activities. 349 students (188 females and 161 males) took part in the study and were aged 9 to 14 with an average age of 11.53 ( $\mathrm{SD}=2.48$ ).

\subsection{Data Collection Tool and Process}

A self-administered questionnaire was used as a data collection tool to describe data on variables of interest. The researchers developed the tool. One of the researchers is a pedagogical expert of biology, and the other is a geological engineer who was a team member for the TAE-II mission to Antarctica in 2018. The data collection tool was named "Questionnaire on Knowledge and Awareness about Antarctica" and consisted of two parts. Part one was structured to collect demographic information about participants, including their age, class, and gender. The second part contained a blend of 19 dichotomous, multiple-choice, contingency, and open-ended questions. The questionnaire questions were obtained from the literature and the students' questions after the informative speeches one of the authors gave at schools under awareness studies. The feedback provided by students like "I did not know the polar bears and penguins live in separate polars. "To learn that having a science center in Antarctica belongs to Turkey is proudful." quotes are also used as questions. The questionnaire items covered a wide range of up-todate information questions about the poles, the pole in which Antarctica is located, where polar bears and penguins live, and so on. Students were asked to complete the forms in an adequate period according to their own pace. They were instructed to do so after being informed about the scope of the study. The administering of the questionnaire was followed by visits to schools to give a speech on Antarctica's awareness. In this way, it was made sure that the students could make more sense of the information they learned by listening to the speeches; they could pick up answers to the questions asked beforehand, focusing on the task better. For the sake of research ethics, it was explained to the participants that their answers would be held to be used for research purposes only.

\subsection{Data Analysis}

The data obtained with the questionnaire were analyzed using descriptive statistical methods in SPSS package programs (IBM Statistical Package for the Social Sciences
Statistics; Armonk, NY, USA). The descriptive data were shown with numbers (n), percentile (\%), and mean \pm standard deviations. Differences were tested using the chisquare test. The statistical significance level was set to $\mathrm{p}$ $<.05$. The results were handled in line with the answers given for each research question. For this reason, the number of respondents did not prove the standard among research questions. In other words, the respondents and the sample of this research were divergent in some instances. Apart from these, missing data analysis was not performed since participation relied on voluntariness.

\section{RESULT AND DISCUSSION}

The students' replies to the questionnaire items were presented under separate headings regarding their geographical, biological, and climatic facts. The distribution of the items investigating respondents' geographical knowledge, biological knowledge, and climatic knowledge was as ten questions, five questions, and four questions, respectively.

\subsection{Students' geographical knowledge about Antarctica}

The participants' responses to the questions related to the poles' geography (Questions No 2, 3, 7, 8, 9, 17, 21, 22, $23,25)$ are displayed in the tables below. The tables were arranged by taking into account the pattern or format of the questions concerned. The respondents' judgments about the poles are shown in Table 1.

It is seen in Table 1 that a total of 336 students answered question 2, 237 of whom $(70.5 \%)$ stated that (38.3\% females, $32.2 \%$ males) the North Pole hosts more ice than the South Pole. Question 8 answered that 340 students, 136 of whom (40\%) considered the Antarctic continent to be in the Northern hemisphere, while 204 $(60 \%)$ suggested the opposite. To check if there was a significant difference in these responses based on gender variable, chi-square analysis was performed. Such a difference was noticed in Question 2 at the significance level of $\mathrm{p}=0.001$.

Another question concerning Antarctica's geographical features was, "Which continent does not contain a country/state?" The answers to this question are given in Table 2. The highest proportion of the respondents ( $n=209 ; 66.1 \%$ ) provided the correct answer for the question inquiring about the uninhabited continent, which is Antarctica. This response was followed by "America" as pointed out by 27 respondents $(8.5 \%)$, "Other" by 26 respondents $(8.2 \%)$, “Africa” by 20 (6.3\%), "Australia” by 
Table 2 Responses about the continent without a country/state on it

\begin{tabular}{lll}
\hline Continent (S3) & Distribution \\
\hline Antarctica & $\mathbf{n}$ & $\mathbf{0 \%}$ \\
America & 209 & 66.1 \\
Other & 27 & 8.5 \\
Africa & 26 & 8.2 \\
Australia & 20 & 6.3 \\
Asia & 19 & 6.0 \\
Total & 15 & 4.7 \\
\hline
\end{tabular}

Table 3 Responses about the continent enclosing the South Pole

\begin{tabular}{lll}
\hline & Distribution \\
Continent (S7) & $\mathbf{n}$ & $\mathbf{0}$ \\
\hline Antarctica & 211 & 64.9 \\
Alaska & 42 & 12.9 \\
Africa & 29 & 8.9 \\
Asia & 20 & 6.2 \\
America & 15 & 4.6 \\
Other & 8 & 2.5 \\
Total & 325 & 100 \\
\hline
\end{tabular}

$19(6.0 \%)$, and "Asia" by another 15 respondents (4.7\%), respectively.

One question was significantly related to the continent which encapsulates the South Pole. Table 3 shows that 325 students answered this question, but 24 did not do so. Of the former, $211(64.9 \%)$ people could answer it correctly by explaining that the South Pole is situated within the borders of the continent of Antarctica. The second-largest group of respondents $(\mathrm{n}=42 ; 12.9 \%)$ uttered "Alaska", which is at the North Pole. Other wrong answers included "Africa" indicated by 29 students (8.9\%), "Asia" by 20 $(6.2 \%)$, "America" by 15 (4.6\%), and "Other" by eight students $(2.5 \%)$.

Four of the questions about Antarctica's geographical features were dichotomous, requiring the answer of "yes" or "no". The answers in this regard are shown in Table 4.

Table 4 shows that $84.2 \%$ of the students believe that it is possible to go to Antarctica. Besides, $86.2 \%$ think that
Table 5 Responses about the place where the most freshwater is available

\begin{tabular}{lll}
\hline Place (Q25) & Distribution & \\
\hline Groundwater & $\mathbf{n}$ & $\mathbf{\%}$ \\
Rivers & 121 & 38,8 \\
Lakes & 92 & 29,5 \\
Glaciers & 35 & 11,2 \\
Oceans & 34 & 10,9 \\
Other & 15 & 4,8 \\
Total & 15 & 4,8 \\
\hline
\end{tabular}

Antarctica is glaciated, $78.1 \%$ believe that there is land over there, and $92.5 \%$ believe water on that continent. Apart from these, $41.2 \%$ of the participants pointed out a science base in Antarctica, which belongs to Turkey, while 59\% think the opposite.

Antarctica's noteworthy geographical features are that it holds approximately $69 \%$ of all potable water resources. To see the students' level of awareness on this matter, a question was included to put forward the most extensive freshwater supply location from the students' point of view. The answers are demonstrated in Table 5.

As Table 5 reveals, $38.8 \%$ of the students stated that the highest freshwater is in underground resources. It was followed by other suggestions, including rivers (29.5\%), lakes $(11.2 \%)$ and, lastly, glaciers $(10.9 \%)$. As a final point, it was found out that a smaller portion of the respondents $(4.8 \%)$ see oceans as a source of fresh water.

\subsection{Students' biological knowledge about Antarctica}

In the questionnaire, some of the items were designed to address Antarctica's biological facts in the students' eyes (Question No 5, 6, 12, 14, 16). The answers obtained from these questionnaire items are presented in the tables below. The contents of the tables were arranged according to their relevance to biology and the consistency of format.

Three of the biology questions were close-ended, requiring a positive or negative one-word answer. Answers to these questions can be seen in Table 6 . It is seen that $88.6 \%$ of the students think that Antarctica hosts some

Table 4 Yes/No questions and answers about Antarctica

\begin{tabular}{|c|c|c|c|c|}
\hline Questionnaire Item & $\begin{array}{l}\text { Yes } \\
\text { n ( } \%)\end{array}$ & $\begin{array}{l}\text { No } \\
\text { n (\%) }\end{array}$ & $\begin{array}{l}\text { Answers } \\
\text { Total }\end{array}$ & $\begin{array}{l}\text { No Answer } \\
\text { Total }\end{array}$ \\
\hline Q9 Is it possible to travel to Antarctica? & $287(84.2 \%)$ & $\begin{array}{l}54 \\
(15.8 \%)\end{array}$ & 341 & 8 \\
\hline Q21 Does Turkey have a science base in Antarctica? & $132(41.8 \%)$ & $\begin{array}{l}190 \\
(59.0 \%)\end{array}$ & 322 & 27 \\
\hline Q23 Is there water in Antarctica? & $310(92.5 \%)$ & $\begin{array}{l}25 \\
(7.5 \%)\end{array}$ & 335 & 14 \\
\hline
\end{tabular}


Table 6 Yes/No questions and answers about Antarctica

\begin{tabular}{|c|c|c|c|c|}
\hline Questionnaire Item & $\begin{array}{l}\text { Yes } \\
\text { n }(\%)\end{array}$ & $\begin{array}{l}\text { No } \\
\text { n ( } \%)\end{array}$ & $\begin{array}{l}\text { Answers } \\
\text { Total }\end{array}$ & $\begin{array}{l}\text { No Answer } \\
\text { Total }\end{array}$ \\
\hline Q12 Are there animal species living in Antarctica? & $302(88.6 \%)$ & $\begin{array}{l}39 \\
(11.4 \%)\end{array}$ & 341 & 8 \\
\hline $\begin{array}{l}\text { Q14 Can all of the plants you see around live in } \\
\text { Antarctica? }\end{array}$ & $\begin{array}{l}39 \\
(11.4 \%)\end{array}$ & $302(88.6 \%)$ & 341 & 8 \\
\hline $\begin{array}{l}\text { Q16 Do you think some people settled and live in } \\
\text { Antarctica? }\end{array}$ & $173(57.6 \%)$ & $131(42.4 \%)$ & 309 & 40 \\
\hline
\end{tabular}

Table 7 Questions and answers about the habitat of penguins and polar bears

\begin{tabular}{llllllllll}
\hline $\begin{array}{l}\text { Questionnaire } \\
\text { Item }\end{array}$ & $\begin{array}{l}\text { North } \\
\text { Pole }\end{array}$ & $\begin{array}{l}\text { South } \\
\text { Pole }\end{array}$ & Africa & $\begin{array}{l}\text { South } \\
\text { America }\end{array}$ & Europe & $\begin{array}{l}\text { North } \\
\text { America }\end{array}$ & Asia & Other & Total \\
\hline Q5 Where do & 223 & 56 & 7 & 1 & - & - & - & 8 \\
polar bears live? & $(75.6 \%)$ & $(9.0 \%)$ & $(2.4 \%)$ & $(0.3 \%)$ & & & 295 \\
Q6 Where do & 173 & 108 & - & - & 3 & 11 & 2 & $(2.7 \%)$ & $(100 \%)$ \\
penguins live? & $(57.1 \%)$ & $(35.6 \%)$ & & & $(1.0 \%)$ & $(3.6 \%)$ & $(0.7 \%)$ & $(2.0 \%)$ & $(100 \%)$ \\
\hline
\end{tabular}

animal species, $88.6 \%$ think that the plant species in their environment cannot survive in Antarctica, and 57.6\% think that there are habitats in Antarctica.

Thanks to the printed and visual media, today, it is wellknown that penguins and polar bears, two of the animals that first come to mind when Earth's poles are referred to, do not live together. To find out the students' knowledge, the questions in Table 7 were addressed, and their answers were noted. The North Pole was mentioned at the highest rate under both of the questions. In other words, the students think that polar bears and penguins mostly live at the North Pole. Still, the conception that polar bears live at the North Pole was more weighted than penguins' misconception. The cross-tabulation analysis further found that $36.8 \%$ of students think that both polar bears and penguins live at the North Pole, and another $5.8 \%$ think that both of the species live at the South Pole. In total, $42.6 \%$ of surveyed participants believe that penguins and polar bears live in the same region. From the perspective of gender, these questions' answers did not differ significantly between girls and boys.

\subsection{Students' climatic knowledge about Antarctica}

A number of the questionnaire items (Question No 1, $4,10,20)$ were planned to unearth students' knowledge and awareness about climate conditions. The participants' answers are listed below by showing due diligence to the consistency of both content and style of the questions. The views of the students regarding the poles are summarized in Table 8

According to Table 8, 245 (71.3\%) of the respondents stated that the coldest place in the North Pole, and another $213(65.9 \%)$ pointed out that the world's coldest and windiest part is, again, the North Pole. However, the correct answer to both questions should be "the South Pole". To test whether the questions' responses have a statistically significant gender difference, chi-square analysis was performed. As a result, a difference was found in answers to Questionnaire Item 1 at the significance level of $\mathrm{p}=0.001$.

Another item regarding the climatic facts was designed to determine whether global warming could affect Antarctica in students' perceptions. 310 persons $(91.7 \%)$ answered in the affirmative, whereas 28 persons $(8.3 \%)$ responded negatively. These are shown in Table 9. 310 persons $(91.7 \%)$ answered in the affirmative, whereas 28 persons $(8.3 \%)$ responded negatively.

In this group of questions, it was also surveyed whether students could travel to Antarctica. Those who replied positively were asked to mark the best choice symbolizing the three months as the ideal season. The distribution of the answers is given in Table 10.

The best time to visit Antarctica is from December to February. In reply to the question in Table 10, 37.1\% of the respondents chose this December-January-February option. Contrarily, the June-July-August period was preferred by $46.6 \%$ of all students. The sum of the remaining options was equal to $16.4 \%$.

This study was carried out to get the picture of Antarctica's knowledge by giving students a questionnaire consisting of items concerning general and current facts about the continent. The participants' answers were processed using simple statistical methods, and the results were divided into three categories. These categories were titled with relevance to geographic, biological, and climatic attributes of Antarctica.

In our findings, $60 \%$ of the students could accurately tell in which hemisphere Antarctica is located. Also, 64\% are seen to know which continent accommodates the South Pole. It can thus be said that the students can associate Antarctica and the South Pole well. Still, the rate of wrong answers seems too striking, considering this particular piece of knowledge. To clarify, 35,1\% of our participants hold false conceptions about the continent, which shelters the South Pole, and another $40 \%$ deem that Antarctica lies in the Northern Hemisphere. Additionally, 
Table 8 Questions and answers about the North and South Pole

\begin{tabular}{|c|c|c|c|c|c|}
\hline \multirow[b]{2}{*}{ Questionnaire Item } & \multicolumn{2}{|c|}{ The North Pole } & \multicolumn{2}{|c|}{ The South Pole } & \multirow[b]{2}{*}{ Total } \\
\hline & Female & Male & Female & Male & \\
\hline
\end{tabular}

Table 9 Responses to "Does global warming have an impact on Antarctica?"

\begin{tabular}{lllll}
\hline $\begin{array}{l}\text { Questionnaire } \\
\text { Item }\end{array}$ & $\begin{array}{l}\text { Yes } \\
\mathbf{n}(\mathbf{\%})\end{array}$ & $\begin{array}{l}\text { No } \\
\mathbf{n}(\mathbf{\%})\end{array}$ & $\begin{array}{l}\text { Answers } \\
\text { Total }\end{array}$ & $\begin{array}{l}\text { No } \\
\text { Answer } \\
\text { Total }\end{array}$ \\
\hline $\begin{array}{l}\text { Q20 Does } \\
\text { global warming } \\
\text { have an impact } \\
\text { on Antarctica? }\end{array}$ & 310 & 28 & 338 & 11 \\
\hline
\end{tabular}

Table 10 Students' suggestions for best months for travel to Antarctica

\begin{tabular}{lll}
\hline & Distribution & \\
Season (Q10) & $\mathbf{n}$ & $\mathbf{0}$ \\
\hline June-July-August & 117 & 46,6 \\
December-January-February & 93 & 37,1 \\
September-October-November & 24 & 9,6 \\
March-April-May & 17 & 6,8 \\
Total & 251 & 100 \\
\hline
\end{tabular}

the percentage as high as $70,5 \%$ of students who feel that the North Pole is home to glaciers suggests a lack of geographical apprehension about Antarctica. A study held in Turkey revealed that $50 \%$ of people involved in the study have difficulties in finding the directions and the placement of countries on the map (Kaya, 2012; Tuna, Demirci \& Gültekin, 2012).

Another question probing geographical information was about the location where the highest quantity of potable water is available. Although the North Pole is covered in sea ice, those sea ice trapped some salt in the small pockets between ice crystals; consequently, that type of water is not drinkable at first for many creatures. On the other hand, $90 \%$ of the glaciers are deposited in Antarctica, and these terrestrial glaciers are made up of frozen fresh waters that can be used by living things. Therefore, it would be quite sensible to call Antarctica the world's big water bottle. However, $38.8 \%$ of the participants here accept underground waters as the primary freshwater resource on Earth.

What is more, "glaciers", which is honorable among all six options under the question, ranked fourth based on the corresponding percentage of $10.9 \%$. These figures imply that the students are not knowledgeable about Antarctic freshwater reservoirs. People associate water and Antarctica only with sea-level rise as the glaciers melt (Shabudin, Rahim, \& Ng, 2016).
After the expedition to Antarctica in 2019, Turkey completed a third explorative visit to the continent, followed by the fourth in 2020. As a result of these missions, a temporary science base was established on the continent during the 2019 visit. Moreover, at the time of our survey, Turkey's science base was not in its place in Antarctica. For this reason, regarding this question, negative responses were taken as the correct answer, but the opposite was deemed wrong. In summary, $41.8 \%$ of the students provided a wrong answer assuming a science base while filling in the questionnaire.

When it comes to knowledge of Antarctica's biological dimensions, the responses concerning the habitat of polar bears and penguins revealed that they have only a naive understanding of this topic. Recently, polar bears have been significantly related to global warming, and they are being given a large place in both the printed and visual media. That is why they are one of the animal species the most familiar to children in general. In a longitudinal study conducted on children aged 4 to 10 in the UK, polar bears and penguins were put in the list of the most known animals rather than creatures living in the rain forests even though the natural habitat of the latter is similar to that of human beings (Palmer, \& Suggate, 2004). This finding was explained with the background knowledge children learned from the TV show "Life in the Freezer" (Palmer, \& Suggate, 2004). On the contrary, our research students signaled only a modest intellectual level about the two prominent species peculiar to the polar regions, penguins and polar bears. Even though most of our respondents $(75.6 \%)$ could spot the natural habitat of polar bears accurately, which is the North Pole, they marked the same option as penguins' habitat as well, producing a wrong answer $(57.1 \%)$.

Moreover, $42.6 \%$ of the research participants think that penguins and polar bears share the same living area in the north or south edge of the globe. This result can be accounted for by students' inadequate information about exactly where these two different animals live, although these species are associated with Earth's poles. The reason for this may be the source of information where they have. Salazar (2012) found that $29.1 \%$ of Santiago residents and $42,5 \%$ of Punta Arenas residents have information about Antarctica from TV.

About the last component of the biological notions, $57.6 \%$ of our participants believe that humans live in Antarctica, which is uninhabited in practice. The truth is 
that there is life at the North Pole, not at the South Pole. Apart from that, the students stated that some animal species could live there, but it is not the case for plant species. However, two types of flowering plants are already known to exist on the continent alongside various mosses, lichens, liverworts, and fungi (McFadyen, 2011). As far as this finding is concerning, it can be said that the students are deficient in some biological matters related to Antarctica.

Lastly, the findings reached from four items about Antarctica's climatic conditions reveal that the students have inadequate information about this continent. They suppose that the North Pole is colder than the other, and the North Pole is the coldest and windiest part of the world. However, the correct answer for both of the questions must be "the South Pole". As another finding, students who think that one can go to Antarctica believe that the best season is from June to August $(46.6 \%)$. However, the fact is that the right time to visit that continent covers December, January, and February because Antarctica is located in the South Hemisphere. The students cited the summer months because they tend to expect high temperatures in the other half of Earth when the temperatures are highest across the Northern Hemisphere. Besides these, the rate of students who think that global warming impacts Antarctica was found to be $91.7 \%$.

\section{CONCLUSION}

When all of the findings as to students' geographical, biological, and climatic knowledge are evaluated all together, it becomes clear that the students predominantly associate Antarctica with the North Pole. The students might have connected the north with cold weather and the south with hot temperatures simply because of their hemisphere. This inference is based on several findings. For example, they said that polar bears and penguins both live at the North Pole, and they referred to summer months for any potential visit to Antarctica. Further evidence includes their arguments that the most massive glaciers are located at the North Pole, the coldest pole of Earth is the North Pole, and the coldest and windiest place is the North Pole again. Students anticipate that the weather gets colder as one moves further north and gets warmer towards the south. Hence, it can be suggested that the north's direction brings cold weather to mind mainly because we live in the North Hemisphere. Consequently, this might have led to the formation of geographical, biological, and climatic misconceptions about Antarctica on students' minds. From the quality of the answers reported here, it can be inferred that the knowledge of students about Antarctica is far from being sufficient.

In light of the preceding, the recommendation is that students' knowledge and awareness must be increased since Antarctica bears particular importance as the world's most significant freshwater resource. Secondly, they should be taught the steps taken in our country about Antarctica. Thirdly, this topic should be inserted into Turkey's formal curriculum by modeling practices in different countries. Specifically, it needs to be made sure that teaching of Antarctica's location and general characteristics should be realized in a more meaningful way as a part of Geography or Social Studies lessons. Besides this, topics such as the importance of water for living things can be taught with special consideration of Antarctica's aqueous features within the scope of Biology and Science lessons. Also, life forms on this continent can be elaborated in the abovementioned school lessons. Finally, the results obtained in this research apply to a relatively limited universe. Thus, it is recommended to replicate or adapt this study to different samples for increased generalizability.

\section{ACKNOWLEDGMENT}

The data used in this research were obtained on the TAE-II, which was carried out under the auspices of the Presidency of the Republic of Turkey, under the responsibility of the Ministry of Science, Industry, and Technology of the Republic of Turkey, in coordination with the Istanbul Technical University Polar Research and Application and Research Centre. The authors are grateful to these institutions for their respective support.

\section{REFERENCES}

Australian Science Teachers Association (ASTA). (2007). Antarctic Science. A resource book of ideas for teachers for National Science Week. https://asta.edu.au/generic/file-widget/download/id/1165.

Azzolini, R., Campus, P., \& Weber, J. (2012). The polar ocean in a warming planet: Understanding for managing a unique resource of the humankind. EGU General Assembly Conference Abstracts, 14,13660 .

Bastmeijer, K. and Roura, R. (2008). Environmental impact assessment in Antarctica. In:Bastemejer, K. \& Roura, R. Theory and Practice of Transboundary Environmental Impact Assessment. First Edition. Brill/Nijhoff, 175-219. DOI: doi.org/10.1163/ej.9789004164796.i-400.57.

Baydemir, T. (2019). Buzullardan öğreneceklerimiz var. Bilim ve Teknike Dergisi, 618.

Benayas, J., Pertierra, L., Tejedo, P., Lara, F., Bermudez, O., Hughes, K., and Quesada, A. (2013). A review of scientific research trends within ASPA No. 126 Byers Peninsula, South Shetland Islands, Antarctica. Antartic Science, 25(2), 128-145. DOI:10.1017/S0954102012001058.

Benn, D. I. \& Evans, D. J. A. (2010). Glaciers and Glaciation. Second Edition, Routledge, New York, USA.

Cohen, L., Manion L. \& Morrison, K. (2007). Research Methods in Education. New York, NY: Routledge.

Dahl-Jensen, D. (2018). Drilling for the oldest ice. Nature Geoscience, 11, 702-706.

Drake, M. J. (2015). Origin of water in the terrestrial planets. Meteoritics and Planetary Science, 40(4), 1-9.

Drewry, D.J. (2009). The future of Antarctic scientific research. Polar Record, 29(168), 37-44.

Elkins-Tanton, L. T. (2011). Formation of early water oceans on rocky planets.Astrophysics and Space Science, 332(2), 359-364. DOI: 10.1007/s10509-010-0535-3.

Garcia, C. V., Robertson, W.H., Lougheed, V., Tweedie, C. \& Velasco, A. (2013). Journey to the End of the Earth: Academic and Professional Benefits for Students Participating in a Field-Based 
Research Program in Antarctica. Journal of College Science Teaching 42(4), 72-81.

Genda, H. (2016). Origin of Earth's oceans: An assessment of the total amount, history and supply of water. Geochemical Journal, 50(1), 2742. DOI: doi.org/10.2343/geochemj.2.0398.

Gröndahl, F., Sidenmark, J. \& Thomsen1, A. (2009). Survey of waste water disposal practices at Antarctic research stations, Polar Research, 28(2), 298-306. DOI: 10.1111/j.1751-8369.2008.00056.x

Karahalil, M., Özsoy, B., Oktar, Ö., Yirmibeşoğlu, S. \& Vural, D. (2018). Türkiye'de kutup bölgeleri hakkında farkındalığı arttırmak üzere yapılan çalışmalar. II. Kutup Bilimleri Calıștayı Özet Kitabı, 86, 12-13 Eylül, İsanbul-Türkiye.

Karataş, F. Ö., Köse, A. G. S. \& Coştu, A. G. B. (2003). Öğrenci Yanılgılarını ve Anlama Düzeylerini Belirlemede Kullanılan İki Aşamalı Testler. Pamukkeale Unniversitesi Eğitim Fakültesi Dergisi, 13(13), 54-69.

Kaya, E. (2012). İlköğretim öğrencilerinin küresel konumlandırma becerileriyle medyadan yararlanma durumları ve sosyal bilgiler dersindeki başarıları arasındaki ilisski. Türkiye Sosyal Araştırmalar Dergisi, 16(2).

Lucchitta, B.K. \& Fergusson, H.M. (1986). Antarctica: Measuring glacier velocity from satellite images. Science, 234(4780), 1105-1108. DOI: 10.1126/science.234.4780.1105.

Marty, B. \& Yokochi, R. (V). Water in the early Earth. Reviews in Mineralogy and Geochemistry, 62(1), 421-450. DOI: doi.org/10.2138/rmg.2006.62.18

McFadyen, E. (2011). Antarctic Future - Education Learning about Antarctica in the 21 st Century. A review of selected education resources available to primary teachers. University of Canterbury, Postgraduate Certificate, Postgraduate Certificate in Antarctic Studies.

Özbebek Tunç, A., Akdemir Ömür, G. \& Düren, A. Z. (2013). Cevresel Farkindalık. İ.Ü. Journal of Faculty of Political Science, O(47), 227-246.

Palmer, J.A. \& Suggate, J. (2004) The development of children's understanding of distant places and environmental issues: report of a UK longitudinal study of the development of ideas between the ages of 4 and 10 years. Research Papers in Education, 19(2), 205-237.

Ricci, C. A., \& Egerton, P. (Eds.). (2010). European research in the polar regions: Relevance, strategic context and setting future directions in the European research area (EPB Strategic Position Paper). European Science Foundation.

Robert, F. (2001). The origin of water on Earth. Science, 293(5532), 10561058. DOI:doi.org/10.1126/science.1064051.

Salazar, J.F. (2012). Perceptions and opinion of Antarctic values in Chile. In Liggett, D. \& Hemmings, A.D (Eds.) Exploring Antarctic $V$ alues. Christchurch: University of Canterbury, Gateway Antarctica Special Publication Series.

Shabudin, A. F. A, Rahim, R. A. \& Ng, T. F. (2016). Strengthening scientific literacy on polar regions through education, outreach and communication (EOC). International Journal of Environmental \& Science Education, 11(12), 5498-5515

The National Academy of Sciences (NAS). (2011). Future Science Opportunities in Antarctica and the Southern Ocean, The National Academies Press: Washington DC.

Tuna, F., Demirci, A. \& Gültekin, N. (2012). Temel coğrafi bilgi ve beceriler toplumda ne ölçüde kullanıliyor? Yön, konum ve harita becerilerinde mevcut durum analizi. Milli Eğitim, 195, 211-227.

Ursavaş, N., \& Aytar, A. (2018). Okul öncesi öğrencilerinin su farkındalığı ve su okuryazarlıklarındaki gelişimin incelenmesi. Journal of Research in Informal Environments, 3(1), 19-45.

USGS (2020). How much of the Earth's water is stored in glaciers? https://www.usgs.gov/faqs/how-much-earths-water-storedglaciers?qt-news science products $=0 \#$ qtnews science products.

Vural, D., Yirmibeşoğlu, S., Oktar, Ö. \& Özsoy, B. (2018). Kutup bölgelerindeki bilimsel araștırmaların eğitim ve farkındalık çalışmalarına etkisi, II. Kutup Bilimleri Çalşstayı Özet Kitabı, 76, 12-13 Eylül, İsanbul-Türkiye.
Wu, J., Desch, S. J., Schaefer, L.,Elkins-Tanton, L. T., Pahlevan, K. \& Buseck, P. R. (2018). Origin of Earth'swater: Chondritic inheritance plusnebular ingassing and storage of hydrogen in the core. Journal of Geophysical Research: Planets, 123(10), 2691-2712. 